\title{
Comparison of ellagic acid contents in Korean and Chinese cultivated species of unripe black raspberries
}

\author{
Ki Hoon Lee, Sunoh Kim* \\ B\&Tech Co., Ltd., R\&D Center, Gwangju 61239, Korea
}

\section{한국 및 중국 재배종 미숙과 복분자의 엘라그산 함량의 비교}

\author{
이기훈·김선오* \\ (주)비엔텍 중앙연구원
}

\begin{abstract}
The goal of this study was to investigate the extracts of ellagic acid in Korean and Chinese black raspberries according to harvest time and extraction solvent. This study was also performed to establish a simple and reliable high-performance liquid chromatography-ultraviolet (HPLC/UV) analytical method for the determination of ellagic acid for quality control and to establish baseline data of extracts of Rubus occidentalis (uRo) and Rubus chingii $(\mathrm{u} R c)$ fruits as healthy functional food ingredients. $\mathrm{u} R o$ and uRc were each extracted with $0 \%, 5 \%, 30 \%$, and $\mathbf{7 0} \%$ ethanol. Among the extracts of these two varieties, the $5 \%$ ethanol extracts of $\mathrm{u} R \boldsymbol{r}$ and $\mathrm{u} R \boldsymbol{c}$ showed the highest contents of ellagic acid, 16.56 and $17.27 \mathrm{mg} / \mathrm{g}$, respectively. The specificity was satisfied with retention time and photo-diode array (PDA) spectrum by analysis of ellagic acid using HPLC and comparison with a standard compound. Ellagic acid was validated for its limit of detection (LOD), limit of quantitation (LOQ), precision, and accuracy. It showed a high linearity in the calibration curve, with a coefficient of determination $\left(R^{2}\right)$ of 0.9999 , and the LOD and LOQ values were 0.25 and $0.77 \mu \mathrm{g} / \mathrm{mL}$, respectively. The results showed that $R$. occidentalis and $R$. chingii can be used simultaneously as healthy functional ingredients and natural medicines.
\end{abstract}

Key words : unripe black raspberry, ellagic acid, HPLC, validation, functional food

\section{서 론}

복분자 또는 복분자딸기라 불리는 열매는 우리나라와 중국을 포함하여 아시아 전 지역에서 전통적으로 민간요법 및 기호식품으로 사용되어온 장미과(Rosaceae) 산딸기속 (Rubus)에 속하는 250여종이 넘는 많은 나무딸기류 (rambles) 중 하나로, 한방에서는 덜 익은 열매(미숙과)로 만든 약재를 복분자(覆盆子)라고 하여 식·의약 소재로서 널리 사용되고 있다(1).

우리나라서는 1980 년대에 들어 전라북도 고창군을 시작

*Corresponding author. E-mail : sunoh@korea.ac.kr

Phone : 82-62-528-2201, Fax : 82-62-528-2202

Received 27 June 2018; Revised 31 July 2018; Accepted 1 August 2018.

Copyright (c) The Korean Society of Food Preservation. All rights reserved.
으로 복분자의 재배가 본격적으로 시작되어 전국으로 확대 되었으나 재배법과 재배종에 대한 명확한 자료가 보고되고 있지 않는 실정이다. 따라서 우리나라에서 국내산 복분자 라 함은 토종복분자로 알려진 Rubus coreanus Miquel (Korean black raspberry)을 총칭하고 있다. 그러나 최근 들 어서 국내에서 재배되고 있는 대부분의 복분자의 잎 모양, 꽃 모양과 색, 그리고 열매의 형태가 토종 복분자로 알려진 $R$ coreanus 종과는 다른 점들이 발견되었고, 그에 따라 국내 Rubus 재배종에 대한 계통학적 유연관계를 분석한 결과 고창군을 중심으로 재배가 확대되었던 국내 재배종은 북미가 원산지인 외래종 복분자인 Rubus occidentalis L. (black raspberry)과 더 유사하였다 $(2,3)$. 이러한 연구결과로 미루어 보아 지금까지도 많은 연구논문 및 문헌에 명시된 복분자종의 학명이 명확하게 명시되지 못한 채 과학적인 연구논문과 문헌들에 잘못된 학명으로 발표하는 등의 심각 한 문제가 발생되고 있으며(3), 특히, 산업적으로 식·의약 
소재로 사용된 복분자의 학명을 잘못 표기하는 오류가 현재 건강기능식품 시장에서 사회적 문제로 제기되고 있다.

국립산림과학원에서는 식·약용 자원으로 활용도가 매우 높고 약리활성이 우수한 것으로 잘 알려진 우리나라 토종 복분자 우량품종 육성을 연구하기 시작하였으며 2005년에 정금 1 호를 비롯해 5 종의 토종복분자 우수클론을 육성하여 소규모 시험지를 조성하여 생육상태와 결실특성을 분석하 고 있다(4,5). 하지만, 현재까지도 우리나라 토종 복분자 우량품종 육성에 대한 연구는 산업적으로 활용할 만한 품종 보급과 생산량 확보가 부족한 실정으로 국내 식·의약산업 과 더불어 건강기능식품 원료로 사용되는 복분자의 경우 국내 재배종인 $R$ occidentalis와 중국 재배종을 수입한 중국 화동복분자 종인 Rubus chingii $\mathrm{Hu}$ 종이 국내에서 대부분 유통 중이다.

최근 국내 토종복분자인 $R$ coreanus와 외래종 복분자인 $R$ occidentalis의 생리활성물질과 항산화력을 비교한 연구 결과에 따르면 $R$ occidentalis의 총 폴리페놀 및 플라보노이 드 함량이 더 높게 나타났으며, ABTS 라디칼 소거능과 FRAP assay를 이용한 환원력, 장세포 산화스트레스 보호 역시 $R$ occidentalis가 더 높게 보고됨에 따라 생리활성물질 과 항산화 활성이 모두 $R$ occidentalis 가 $R$ coreanus보다 높은 것을 알 수 있었다(6). 그러나 현재까지도 $R$ coreanus 는 정확한 유전자 분석을 통한 종 판별법이 확립되지 않고 있고, 특히 재배농가에서 조차 재배 중인 복분자 종이 한국 토종 복분자인 $R$ coreanus라는 확증이 어려워 복분자 샘플 링의 신뢰성이 낮은 결과로 보인다.

Choi 등의 연구결과에 따르면 $R$ occidentalis의 생리활성 물질로서 11 종의 성분들에 대한 함량을 분석하였고, 그중 에 엘라그산(ellagic acid)이 가장 함량이 높은 성분으로 보 고하였으며 특히 미숙과 복분자에서 ellagic acid의 함량이 약 7배가 높았다(7). 이후 Chae 등(8)은 ellagic acid를 $R$ occidentalis의 건강기능식품 원료로 사용하기 위한 지표성 분으로 활용하기 위해 표준 분석법을 확립하는 연구를 시도 한 바가 있다. 그러나 사용된 복분자 원료의 성숙된 정도가 표준화되지 않고 성숙도 정도를 명확하게 정해지지 않는 상태의 분석법 연구로서 식·의약 용도로 가장 많이 활용되 는 미숙과 상태에서의 표준 분석법 확립이 완벽하게 이루어 지지 않았다. 또한, 현재 국내에서 식-의약 소재로서 가장 많이 유통되고 혼용되어 사용되고 있는 복분자종인 국내 재배산 $R$ occidentalis종과 중국 수입산 $R$ chingii 종의 지표 성분 함량의 유사성에 대한 비교 연구도 전무한 실정이다.

우리는 선행 복분자의 기능성에 대한 연구를 통해 완숙 과 복분자 추출물보다 미숙과 복분자 추출물에서 체지방 축적 억제 효과 $(9,10)$ 및 콜레스테롤 억제효과(11)가 우수 함을 보고한 바가 있고, 이러한 생리활성 기능의 주요 기능 성물질이 ellagic acid임을 증명하여 보고한 바가 있다(10). 또한 가장 생리활성이 우수한 추출방법을 규명하기 위해
다양한 추출방법을 통해 생리활성을 연구한 결과 미숙과 복분자를 $5 \%$ 주정추출의 조건에서 가장 우수한 생리활성 효과가 있음을 규명하였다(9-11). 그러나 다양한 추출방법 에 따른 각 추출물별 ellagic acid의 함량차이는 규명하지 못하였다.

따라서 미숙과 복분자를 활용하여 건강기능식품을 개발 하고 생산하기 위해서는 국내에서 가장 빈번하게 혼용되어 사용되고 있고 현재 유전자 분석을 통해 종의 구별이 가능 한 두 종의 미숙과 복분자 원료의 표준화와 규격화 연구가 필수적으로 선행되어야 한다. 이러한 연구 필요성을 시작 으로 본 연구에서는 국내에서 가장 많이 재배되고 있고, 유전자 분석을 통해 종의 구별이 가능한 $R$ occidentalis와 중국 화동복분자 $R$ chingii 추출물에 함유된 ellagic acid의 함량 비교를 통해 미숙과 복분자의 건강기능식품 지표성분 을 ellagic acid로 설정하여 국내산과 중국산 미숙과 복분자 원료의 상호 대체 사용 가능성을 확인하고 다양한 추출방법 을 통해 추출한 미숙과 복분자 추출물에서의 ellagic acid 함량을 검토하고자 연구를 수행하였다. 또한 복분자를 포 함하여 다양한 식품에 존재하는 ellagic acid의 HPLC 표준 분석법은 기존의 많은 문헌에서 분석법을 제시하고 있으 나, 이러한 ellagic acid 분석법이 본 연구에 사용한 추출방법 을 달리한 국내산과 중국산 미숙과 복분자 추출물의 표준분 석법으로 적용 가능성과 그 분석법의 유효성을 재검증하여 미숙과 복분자를 이용한 건강기능식품 원료의 표준분석법 으로 적용하기 위한 확정연구를 하고자 하였다.

\section{재료 및 방법}

\section{미숙과 복분자 추출물 제조}

본 실험에서 사용된 복분자는 전라북도 고창군 일대 5 개 농가에서 채취한 것으로 2016년 5월 20일에 채취한 미숙과 (열매 전체가 녹색인 상태), 5월 30일에 채취한 중간 성숙과 (붉은색과 녹색이 섞여 있는 상태) 및 6월 20일에 채취한 완숙과(진한 암적색으로 성숙된 상태)로 구분하여 채취한 다음 열풍건조기(CF-21WF, Jeiotech, Daejeon, Korea)에서 건조 $\left(45^{\circ} \mathrm{C}, 24\right.$ 시간 $)$ 한 후 밀봉하여 냉장보관하고 연구에 사용하였다. 중국 재배종 건조 미숙과 복분자는 서울 경동 약령시장, 대구 약령시장, 제천약령시장에서 각각 5 가지씩 총 15 가지를 녹색을 띄는 정도를 직접 확인하고 구입하여 사용하였다. 구입한 모든 미숙과 복분자는 유전자 분석을 통해 종을 검증한 후 $R$ occidentalis와 $R$ chingii로 확증된 시료를 각각 지역별로 3그룹씩 총 6그룹으로 나누어 본 연구에 사용하였다. 각각의 미숙과 복분자는 여기에 중량 20 배에 해당하는 용매(열수와 $5 \%, 30 \%, 70 \%$ 의 주정)를 첨가한 후 4시간 동안 초고속 진공저온농축추출기 (Cosmos660, Kyungseo machine, Incheon, Korea)를 이용하 
여 추출하였다. 사용한 발효주정은 $95 \%$ 알코올 함량의 발 효주정으로 (주대한주정라이프에서 구입하여 사용하였다. 추출물은 여과하여 대형회전진공농축기(Bühi rotavapor R-220, Gschwader strasse, Flawil, Switzerland)로 $55^{\circ} \mathrm{C}, 50$ $\mathrm{mbar}$ 조건에서 감압농축하고, 각 농축물은 동결건조하여 분말화 하였다. 제조된 분말을 밀봉하여 $4^{\circ} \mathrm{C}$ 에서 냉장 보관 하여 두고 실험에 사용하였다.

\section{표준용액의 조제}

Ellagic acid(Sigma-Aldrich Chemical Co., St. Louis, MO, USA)의 표준원액(stock solution)은 dimethyl sulfoxide (DMSO)에 용해시킨 후 $1,000 \mu \mathrm{g} / \mathrm{mL}$ 의 농도가 되도록 제조 한 다음 이를 $50 \% \mathrm{MeOH}$ 로 희석하여 $0.5,1,5,10$, 및 25 $\mu \mathrm{g} / \mathrm{mL}$ 농도가 되도록 제조한 후 $0.45 \mu \mathrm{m}$ PVDF membrane filter(Millipore, Milford, MA, USA)로 여과한 후 사용하였 다. Ellagic acid 함량은 표준용액의 크로마토그램에서 얻은 피크의 농도별 면적을 이용하여 작성한 표준검량선으로부 터 산출하였다.

\section{시험용액의 조제}

미숙과 복분자 추출 분말의 시험용액은 $\mathrm{Kim}$ 등(12)이 언급한 방법을 응용하였다. 즉, 시험용액은 동결 건조된 분말 일정량을 정밀히 취한 뒤 $50 \%$ methanol을 이용해 충분 히 용해시킨 후 $0.45 \mu \mathrm{m}$ syringe filter로 여과하여 사용하였 다.

\section{HPLC 분석}

미숙과 복분자 추출물의 ellagic acid 분석조건은 Table 1 과 같다. HPLC는 1525 Binary pump, column oven 및 2998 photodiode array detector(Waters HPLC system, Millford, $\mathrm{MA}, \mathrm{USA}$ )를 사용하였고, 데이터 수집 및 처리를 위해 Empower3 software program(Waters Corporation, Milford, $\mathrm{MA}$, USA)을 사용하였다. 분석용 컬럼은 Agilent EclipsXDB-C $\mathrm{C}_{18}$ column $(4.6 \times 250 \mathrm{~mm}, 5 \mu \mathrm{m}$, Agilent, Santa Clara, CA, USA)을 사용하였으며, 이동상 용매 $\mathrm{A}$ 는 $1 \%$ formic acid가 함유된 water를, 용매 $\mathrm{B}$ 는 $100 \%$ acetonitrile를 사용하여 $0.5 \mathrm{~mL} / \mathrm{min}$ 의 유속으로 각각 분석하였다. UV는 $254 \mathrm{~nm}$ 파장에서 측정하였고, 시료 주입량은 $20 \mu \mathrm{L}$ 로 하였 다.

\section{분석법의 유효성 검증}

지표성분의 HPLC 분석법 검증은 의약품 등 시험방법 밸리데이션에 대한 가이드라인(13,14)을 근거하여 특이성 (specificity), 직선성(linearity), 정확성(accuracy), 정밀성 (precision)등을 수행하였으며, 직선성 검증으로부터 얻어 진 검량선의 기울기와 표준편차를 이용해 검출한계(LOD) 및 정량한계 $(\mathrm{LOQ})$ 를 확인하였다. 유효성 검증은 각각의 균질화된 시료(5\% 주정추출물)로 실시하였다.

특이성 검증은 ellagic acid 표준용액과 시료용액을 HPLC 로 분석한 후 크로마토그램을 비교하여 ellagic acid peak의 분리도 및 머무름 시간을 확인하였으며 photo diode array(PDA) spectrum을 측정하여 동일한 spectrum을 나타 내는지 확인하였다.

직선성, 검출한계 및 정량한계(linearity, $\mathrm{LOD}$ and LOQ) 는 단계적으로 희석한 ellagic acid 표준용액을 HPLC로 분 석하여 3회 반복 측정하였으며 peak 면적비에 대한 농도비 의 관계를 나타내는 표준검량선을 작성하였다. 검출한계와 정량한계는 표준용액의 크로마토그램을 이용하여 얻어진

Table 1. Extraction yields of uRo and uRc under different conditions involving different temperatures $\left(75-100^{\circ} \mathrm{C}\right)$ and solvents (aqueous, $5 \%$ (v/v) aqueous ethanol, $30 \%$ (v/v) aqueous ethanol, and 70\%, (v/v) aqueous ethanol)

\begin{tabular}{|c|c|c|c|c|c|}
\hline \multirow{2}{*}{\multicolumn{2}{|c|}{ Name of the extract }} & \multicolumn{4}{|c|}{ Dry matter (\%) } \\
\hline & & $\begin{array}{c}\text { Water extract } \\
100^{\circ} \mathrm{C} \\
\end{array}$ & $\begin{array}{c}5 \% \mathrm{EtOH} \text { extract } \\
100^{\circ} \mathrm{C} \\
\end{array}$ & $\begin{array}{l}30 \% \text { EtOH extract } \\
90^{\circ} \mathrm{C}\end{array}$ & $\begin{array}{l}70 \% \text { EtOH extract } \\
70^{\circ} \mathrm{C}\end{array}$ \\
\hline \multirow{4}{*}{$\mathrm{u} R o^{1)}$} & Sample 1 & 16.50 & 20.36 & 21.46 & 20.31 \\
\hline & Sample 2 & 17.10 & 19.87 & 20.50 & 21.33 \\
\hline & Sample 3 & 16.91 & 21.10 & 22.48 & 21.05 \\
\hline & Mean \pm SD & $16.84 \pm 0.30^{2)}$ & $20.44 \pm 0.61^{* * 33)}$ & $21.48 \pm 0.99^{* *}$ & $20.90 \pm 0.52^{* * *}$ \\
\hline \multirow{4}{*}{$\mathrm{u} R c$} & Sample 4 & 18.84 & 19.0 & 22.29 & 19.78 \\
\hline & Sample 5 & 16.41 & 20.38 & 22.30 & 22.24 \\
\hline & Sample 6 & 17.68 & 19.23 & 21.71 & 20.93 \\
\hline & Mean \pm SD & $17.64 \pm 121^{\mathrm{NS} 4)}$ & $19.54 \pm 0.73^{\mathrm{NS} N \mathrm{NS}}$ & $22.1 \pm 0.33^{* \star} \mathrm{NS}$ & $20.98 \pm 1.23^{*}$ NS \\
\hline Ro & Sample 7 & 4.22 & 6.77 & 7.14 & 7.27 \\
\hline
\end{tabular}

1) $\mathrm{u} R$, unripe Rubus occidentalis $\mathrm{L}$; $\mathrm{u} R c$, unripe Rubus chingii $\mathrm{Hu}$; Ro, ripe Rubus occidentalis $\mathrm{L}$.

${ }^{2)}$ Data are presented as the mean \pm SD.

${ }^{3}$ The data were statistically evaluated using one-way analysis of variance (ANOVA) followed by Dunnett's Multiple Comparison test to compare significant differences between

the groups at ${ }^{N S} p>0.05$ (NS=not significant), ${ }^{*}<0.05,{ }^{*}<<0.01$, and ${ }^{* * *} \mathrm{p}<0.001$.

${ }^{4)}$ Statistically significant from the $\mathrm{u} R O$ groups at ${ }_{\mathrm{NS}} \mathrm{p}>0.05$. 
검량선의 기울기와 표준편차에 근거하여 계산하였다.

$\mathrm{LOD}=3.3 \times$ standard deviation of the response/slope of the calibration curve

$L O Q=10 \times$ standard deviation of the response/slope of the calibration curve

정확성은 표준용액 5,10, 및 $15 \mu \mathrm{g} / \mathrm{mL}$ 를 시료에 첨가하 여 회수율로 확인하였다. 각 시험은 3 회 반복 HPLC로 분석 하여 결과 값이 참값에 근접한지 분석에 의해 회수되는 양을 백분율로 환산하여 확인하였다.

정밀성은 시험용액을 일내분석(intra-day)과 일간분석 (inter-day)으로 나누어 진행하였다. Intra-day는 1 일 3 구간 으로 진행하였으며 각 3회씩 반복하여 HPLC로 분석하였 고, inter-day는 1 일 1 구간으로 3 일간 진행하였다. 정밀성의 확인을 위한 각 시험은 구간마다 3 회 반복하여 분석하여 상대표준편차(relative standard deviation, RSD)로 확인하였 다.

\section{결과 및 고찰}

\section{미숙과 복분자의 특성 및 추출수율}

복분자의 미숙과 상태의 기초적인 기준 설정을 위해 국 내 재배종 미숙과 복분자(unripe Rubus occidentalis, $\mathrm{u} R o$ )와 중국 재배종 미숙과 복분자(unripe Rubus chingii, uRc)의 건조 상태 과실의 형태적 특성을 알아본 결과 $\mathrm{u} R o$ 과중은 평균 $86.33 \pm 0.01 \mathrm{mg} /$ 개, $\mathrm{u} R c$ 과중은 평균 $84.53 \pm 0.01 \mathrm{mg}$ /개 의 범위로 두 종간의 무게는 유의적 차이가 없었다(data not shown). Fig. 1 에서 보는 것과 같이 건조된 $\mathrm{uRo}$ 와 $\mathrm{uRc}$ 의 형태적인 차이는 구별이 어려울 정도로 유사하였고, 건조 과정에서 갈변현상에 의해 연한 갈색을 띄는 것을 볼 수 있었다. 그러나 국내 재배종 복분자가 성숙되기 시작하여 붉은색으로 전환되기 시작하는 시점인 6 월 20 일에 채취한
복분자는 건조 후 확연하게 미숙과 복분자와 구분이 가능할 정도로 색이 진해져 검붉은 색을 띄었다. 또한 과실의 무게 도 $126.3 \pm 0.04 \mathrm{mg}$ /개로 증가하였고 육안적인 관찰만으로도 과실의 크기가 미숙과 복분자에 비해 더 큰 것을 알 수 있었다. Lee 등(15)의 연구에 따르면 복분자 유사종인 산딸 기(Rubus idaeus)의 과중은 700-1,700 mg/개로 본 연구에서 사용한 복분자보다 대체적으로 높은 것을 알 수 있어, 과실 의 무게에 따라 유사종인 산딸기와 종의 구별도 가능할 것으로 사료된다. 이러한 결과로 건조된 복분자의 수확시 기와 형태적인 특징으로 미숙과의 기준을 설정할 수 있을 것으로 사료된다. 추출용매와 추출온도를 달리한 다양한 조건에서 $\mathrm{u} R o$ 와 $\mathrm{u} R c$ 및 국내 재배종 완숙과 복분자(ripe Rubus occidentalis, Ro)를 추출하여 수득한 추출수율은 Table 1 과 같다. 모든 미숙과 복분자의 추출수율은 열수추 출에 비하여 $5 \%$ 주정추출이 유의적으로 높았으나 $(\mathrm{p}<0.001)$, 주정농도에 따른 일정한 경향은 없었다. $\mathrm{u} R o$ 와 $\mathrm{u} R c$ 간의 추출수율은 모든 추출물에서 유의적 차이가 없이 (p>0.05) 비슷한 수준이었다. 그러나 $R O$ 에서는 낮은 추출수 율을 보였으나 이는 완숙과 복분자는 수분함량이 많고 과육 이 약해 열풍건조 또는 동결건조가 불가능하여 생과 자체에 서 추출한 결과로 과실에 함유된 수분에 의해 추출수율이 상대적으로 낮게 측정된 결과이다.

\section{미숙과 복분자 추출물의 원산지별, 에탄올 농도별 ellagic acid 함량}

미숙과 복분자의 원산지별, 에탄올 농도별 ellagic acid 함량을 Table 2 의 조건에서 비교 분석한 결과는 Table 3 과 같다. 국내 재배종 미숙과 복분자 $(\mathrm{u} R o)$ 의 $5 \%$ 주정 추출물이 $16.56 \mathrm{mg} / \mathrm{g}$, 중국 재배종 미숙과 복분자 $(\mathrm{u} R c)$ 의 $5 \%$ 주정 추출물이 $17.27 \mathrm{mg} / \mathrm{g}$ 으로 각각 유의적으로 가장 높은 ellagic acid 함량을 나타내었다. $\mathrm{u} R o$ 의 경우 고창군의 다른 농가에서 구입한 3 가지 복분자의 결과에서 모두 유사한 결과를 볼 수 있었으며, 중국산 $\mathrm{u} R c$ 의 경우도 유사하게 서로 다른 곳에서 구입한 미숙과 복분자에서 모두 유사한
(A)

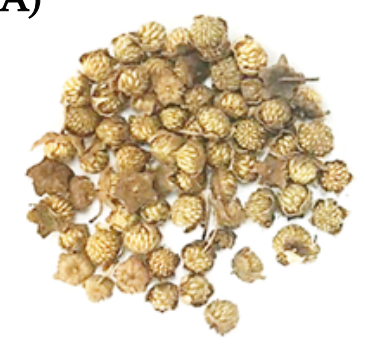

(B)

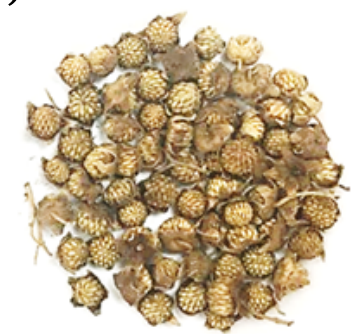

(C)

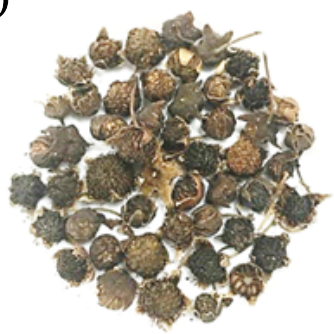

Fig. 1. Photo of dried black raspberries.

A, unripe Rubus occidentalis L.; B, unripe Rubus chingii $\mathrm{Hu}$; C, middle-ripe Rubus occidentalis L. 
Table 2. Analytical condition of HPLC for analysis of ellagic acid

\begin{tabular}{|c|c|c|c|}
\hline Parameters & \multicolumn{3}{|c|}{ Condition } \\
\hline HPLC model & \multicolumn{3}{|c|}{ Waters 1500 -series } \\
\hline Column & \multicolumn{3}{|c|}{ Agilent Eclips $\mathrm{XDB}^{-} \mathrm{C}_{18}(4.6 \times 150 \mathrm{~mm}, 5 \mu \mathrm{m})$} \\
\hline Detector & \multicolumn{3}{|c|}{ UV $254 \mathrm{~nm}$} \\
\hline Flow rate & \multicolumn{3}{|c|}{$0.5 \mathrm{~mL} / \mathrm{min}$} \\
\hline Column temperature & \multicolumn{3}{|c|}{$40^{\circ} \mathrm{C}$} \\
\hline Injection volume & \multicolumn{3}{|c|}{$20 \mu \mathrm{L}$} \\
\hline Mobile phase & \multicolumn{3}{|c|}{ A: $1 \%$ formic acid in water, B: Acetonitrile } \\
\hline \multirow{7}{*}{ Gradient } & Time (min) & $\mathrm{A}(\%)$ & $\mathrm{B}(\%)$ \\
\hline & 0 & 90 & 10 \\
\hline & 7 & 90 & 10 \\
\hline & 28 & 45 & 55 \\
\hline & 32 & 30 & 70 \\
\hline & 35 & 90 & 10 \\
\hline & 40 & 90 & 10 \\
\hline
\end{tabular}

경향으로 ellagic acid 함량이 검출되었다. 에탄올 농도에 따른 추출물의 ellagic acid 함량은 5\% 주정 > 열수 > 70\% 주정 > $30 \%$ 주정 추출물 순으로 나타났으며, 가장 낮은 $30 \%$ 주정 추출물은 국내산과 중국산이 각각 $9.31 \mathrm{mg} / \mathrm{g}$ 과 $9.01 \mathrm{mg} / \mathrm{g}$ 으로 열수추출물보다 유의적(p<0.001) 으로 낮은 수준의 ellagic acid 함량이 나타났다. 또한 국내산과 중국산 미숙과 복분자의 ellagic acid 함량은 각 에탄올 농도별로 두 시료 간 함량 차이가 없음을 확인 할 수 있었다. 완숙과 복분자 추출물의 ellagic acid 함량은 과실이 숙성되어갈수 록 ellagic acid 함량이 감소하였고 에탄올 농도가 높아질수 록 유의적으로 ellagic acid 함량이 높아졌으나 ellagic acid 함량 자체가 상대적으로 매우 낮아 추출방법별 비교의 의미 는 크지 않다고 사료된다. Choi 등(7)은 고창군에서 재배된
미숙과 복분자 열수 추출물에서 $8.50 \mathrm{mg} / \mathrm{g}, 75 \%$ 주정 추출 물에서 $6.19 \mathrm{mg} / \mathrm{g}$ 으로 보고하였으며 본 연구결과보다는 약간 낮은 수준으로 이는 채취 일자의 차이 및 추출용매와 추출시간의 차이 때문에 나타난 함량차이 때문인 것으로 사료되며 완숙과 복분자보다 미숙과 상태의 복분자에서 약 7배가 높게 ellagic acid가 검출된 것은 본 연구결과와 유사하다고 볼 수 있다. 그러나 가장 ellagic acid함량이 높은 $5 \%$ 주정추출물은 확인하지 않았기 때문에 본 연구에서는 기능성 성분으로서 ellagic acid가 가장 많이 추출 될 수 있는 $5 \%$ 주정추출 조건을 확립하였다는데 큰 의미가 있다 고 판단되고, 우리의 선행연구에서 $5 \%$ 주정으로 미숙과 복분자를 추출 하였을 때 가장 생리활성이 높은 결과가 $5 \%$ 주정추출물에서 기능성 성분인 ellagic acid가 가장 많이 추출되었기 때문이라는 것을 유추할 수 있을 것으로 사료된 다. 따라서 미숙과 복분자를 산업적으로 식·의약 소재로 활용할 경우 $5 \%$ 주정추출 방법이 가장 적절하다고 결정하 여 미숙과 복분자 $5 \%$ 주정추출물의 지표성분으로서 ellagic acid를 설정하기 위해 기존의 ellagic acid의 분석법을 미숙 과 복분자의 $5 \%$ 주정추출물에 적용가능성을 확인하고 재 검증하여 그 결과를 표준분석법으로 활용하고자 하였다.

\section{특이성}

특이성 시험을 통해 ellagic acid 표준용액과 시험용액의 크로마토그램을 비교하여 다른 물질과의 간섭 없이 표준물 질의 peak가 분리되는지 확인하였다. 표준용액과 원산지별 미숙과 복분자 $5 \%$ 주정 추출물을 비교한 결과, 약 16.5 분대 에서 ellagic acid peak가 동일하게 검출됨을 확인하였고, 시험용액에서 다른 peak와 간섭 없이 완전히 분리됨을 확인 할 수 있었다. 또한 표준용액과 시료용액의 PDA spectrum 도 동일한 패턴을 나타내어 본 시험법의 특이성을 확인할 수 있었다(Fig. 2).

Table 3. The ellagic acid content of black raspberry extracts as affected by ethanol concentration

\begin{tabular}{|c|c|c|c|c|c|}
\hline \multirow{2}{*}{\multicolumn{2}{|c|}{ Name of the extract }} & \multicolumn{4}{|c|}{ Ellagic acid (mg/g) } \\
\hline & & water & $5 \% \mathrm{EtOH}$ & $30 \% \mathrm{EtOH}$ & $70 \% \mathrm{EtOH}$ \\
\hline \multirow{4}{*}{$\mathrm{u} R \delta^{1)}$} & Sample 1 & $12.40 \pm 0.21^{2)}$ & $16.56 \pm 0.19^{* * * 3)}$ & $9.31 \pm 0.21^{\# \#}$ & $10.03 \pm 0.66^{\# \#}$ \\
\hline & Sample 2 & $11.44 \pm 0.12$ & $15.57 \pm 0.58^{* * *}$ & $10.510 .63^{\#}$ & $11.670 .52^{\mathrm{N} . \mathrm{S}}$ \\
\hline & Sample 3 & $12.01 \pm 0.18$ & $15.24 \pm 1.02^{* * *}$ & $10.02 \pm 1.40^{\#}$ & $11.96 \pm 0.18^{\mathrm{N} . \mathrm{S}}$ \\
\hline & Mean \pm SD & $11.95 \pm 0.48$ & $15.79 \pm 0.68^{* * *}$ & $9.95 \pm 0.60^{\#}$ & $11.22 \pm 1.04^{\mathrm{N} . \mathrm{S}}$ \\
\hline \multirow{4}{*}{$\mathrm{u} R c$} & Sample 4 & $11.35 \pm 0.24$ & $16.77 \pm 0.48^{* * *}$ & $9.01 \pm 0.77^{\# \# \#}$ & $11.13 \pm 0.38^{\mathrm{NSS}}$ \\
\hline & Sample 5 & $9.78 \pm 0.57$ & $17.27 \pm 0.27^{* * *}$ & $9.42 \pm 0.09^{\text {N.S. }}$ & $11.05 \pm 0.14^{* *}$ \\
\hline & Sample 6 & $12.07 \pm 0.42$ & $16.48 \pm 0.16^{* * *}$ & $9.87 \pm 0.45^{\# \# \#}$ & $10.98 \pm 0.28^{\# \#}$ \\
\hline & Mean \pm SD & $11.07 \pm 1.17$ & $16.84 \pm 0.40^{* * *}$ & $9.43 \pm 0.43^{\# \#}$ & $11.05 \pm 0.08^{\mathrm{N} . \mathrm{S}}$ \\
\hline Ro & Sample 7 & $0.54 \pm 0.02$ & $0.91 \pm 0.01^{* * *}$ & $0.67 \pm 0.05^{* * *}$ & $1.03 \pm 0.07^{* * *}$ \\
\hline
\end{tabular}

\footnotetext{
1) $\mathrm{u}$ Ro, unripe Rubus occidentalis $\mathrm{L}$; $\mathrm{u} R c$, unripe Rubus chingii $\mathrm{Hu}$; Ro, ripe Rubus occidentalis $\mathrm{L}$.

${ }^{2)}$ Data are presented as the mean \pm SD.

${ }^{33}$ The dat were statistically evaluated using one-way analysis of variance (ANOVA) followed by Dunnett's Multiple Comparison test to compare significant differences between the groups at ${ }^{* / \#} \mathrm{p}<0.05,{ }_{* * / \#} \mathrm{p}<0.01$ and ${ }^{* * * / \#+m} \mathrm{p}<0.001$. $^{* / \#}$ Statistically significant from the water extract group.
} 

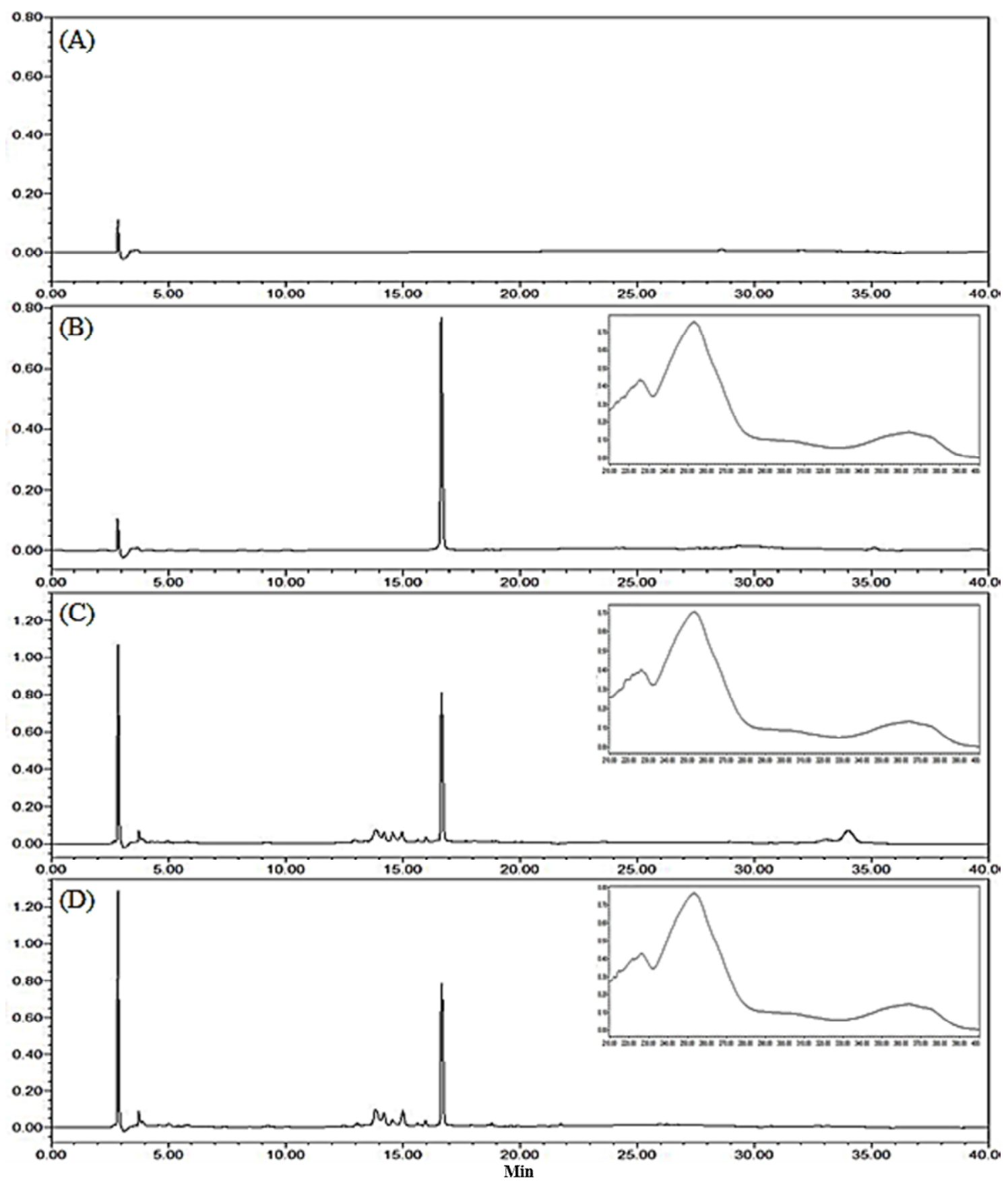

Fig. 2. HPLC chromatogram and PDA spectrum of (A) Blank, (B) ellagic acid standard, (C) 5-uRo extract, and (D) 5-uRc extract at $254 \mathrm{~nm}$ by a photodiode array detector.

직선성, 검출한계 및 정량한계

표준품 ellagic acid를 $0.5,1,5,10$, 및 $25 \mu \mathrm{g} / \mathrm{mL}$ 의 농도로 단계적으로 희석한 뒤 HPLC로 분석하여 표준검량선을 작 성하였다(Fig. 3). 검량선의 결정계수 $\left(\mathrm{R}^{2}\right)$ 는 0.9999으로 높 은 직선성을 보였으며, 검출한계는 $0.25 \mu \mathrm{g} / \mathrm{mL}$, 정량한계는 $0.77 \mu \mathrm{g} / \mathrm{mL}$ 이었다. 이 결과는 시료에 적용할 경우 검출한계 는 $0.25 \mu \mathrm{g} / \mathrm{mL}$ 수준으로 검출이 가능하고, 정량한계는 0.77 $\mu \mathrm{g} / \mathrm{mL}$ 수준까지 정량할 수 있는 최저 농도를 의미한다.

\section{정확성 및 회수율}

지표성분의 농도별 시험용액을 국내산과 중국산 미숙과 복분자 $5 \%$ 주정추출물로 각각 나누어 조제하여 HPLC 분석 에 의해 회수되는 양을 확인하였다. Table 4에 나타난 바와 같이 ellagic acid의 회수율은 국내산은 97.54-101.01\%, 중국 산은 98.16-99.25\% 범위의 회수율을 보였다. Kim 등(12)은 ellagic acid 분석방법 검증에서 89.17-97.92\%의 회수율을 보였으며, Chae 등(8)은 89.08-100.22\%의 회수율을 얻어 


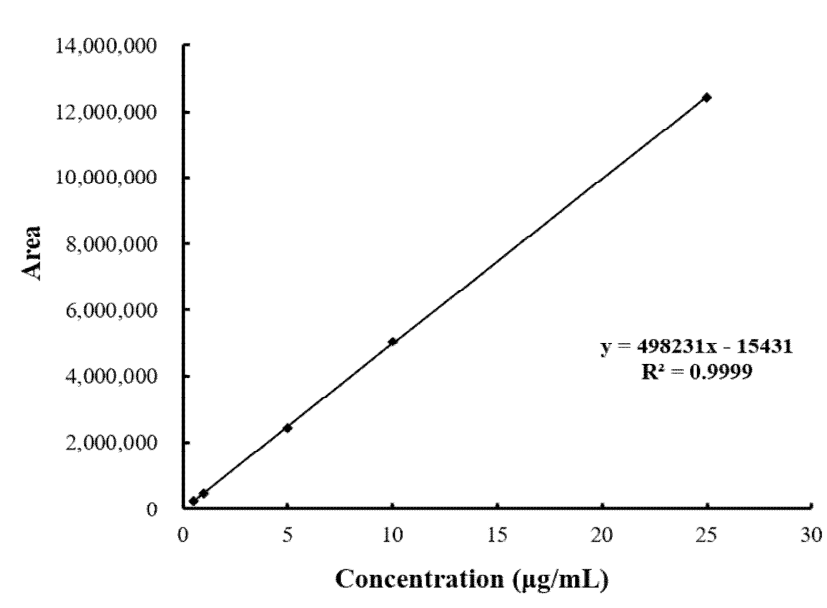

Fig. 3. Calibration curve of ellagic acid standard.

Table 4. Intra- and inter-day precision and accuracy data of the HPLC method for the determination of ellagic acid in black raspberry extracts

\begin{tabular}{ccccc}
\hline & $\begin{array}{c}\text { Concentration } \\
(\mu \mathrm{g} / \mathrm{mL})\end{array}$ & $\begin{array}{c}\text { Intra-day } \\
(\mathrm{RSD} \%)^{1)}\end{array}$ & $\begin{array}{c}\text { Inter-day } \\
(\mathrm{RSD} \%)\end{array}$ & $\begin{array}{c}\text { Recovery } \\
(\%)\end{array}$ \\
\hline $5-\mathrm{u} R \sigma^{2)}$ & 5 & 0.54 & 3.15 & $99.37 \pm 0.86^{4)}$ \\
& 10 & 1.30 & 2.95 & $97.54 \pm 1.15$ \\
& 15 & 0.85 & 2.23 & $101.01 \pm 0.17$ \\
\hline $5-\mathrm{u} R c^{3)}$ & 5 & 2.21 & 2.58 & $99.25 \pm 1.51$ \\
& 10 & 1.69 & 2.79 & $98.71 \pm 0.50$ \\
& 15 & 0.48 & 1.57 & $98.16 \pm 1.10$ \\
\hline
\end{tabular}

${ }^{1)}$ Relative standard deviation.

${ }^{2)}$ Dried $5 \%$ ethanol extract of uRo.

${ }^{3}$ Dried 5\% ethanol extract of uRc.

${ }^{4}$ Each value represents the mean $\pm \mathrm{SD}(\mathrm{n}=3)$.

본 연구결과와 유사한 결과를 보였다.

\section{정밀성}

분산정도를 나타내는 정밀성은 균일한 하나의 시료로부 터 여러 번 반복 채취하여 정해진 조건에 따라 측정하였을 때 각각의 측정값들 사이의 근접성을 의미하며, Table 4 와 같이 intra-day와 inter-day로 나누어 상대표준편차(RSD)를 측정하였다. Intra-day 분석에서의 정밀도는 국내산과 중국 산 미숙과 복분자 $5 \%$ 주정추출물이 각각 $0.54-1.30 \%$ 와 0.48-2.21\%이었으며, inter-day분석에서의 정밀도는 국내 산과 중국산 미숙과 복분자 $5 \%$ 주정추출물이 각각 $2.23-3.15 \%$ 와 $1.57-2.79 \%$ 이었다.

이상의 분석결과, 국내에서 유통되고 산업적으로 식·의 약 소재로 가장 많이 사용되고 있는 두 가지 종의 미숙과 복분자 추출물을 기능성 원료로 활용하기 위한 표준화된 ellagic acid 분석법의 유효성을 검증하였고, 유효성 검증 및 HPLC 분석을 통해 5\% 주정추출물이 가장 높은 ellagic acid의 함량을 보이는 추출방법을 규명하였다, 비록 미숙과
복분자에 함유되어 있는 다른 성분들도 같은 경향으로 $5 \%$ 주정추출물에서 많이 추출되는지에 대한 추가 연구는 필요 할 것으로 판단되나 본 연구결과로 국내 재배종인 $\mathrm{uRo}$ 와 중국 재배종인 $\mathrm{u} R c$ 미숙과 복분자의 ellagic acid 함량 차이 가 거의 없어 ellagic acid를 지표성분으로 설정한 경우에 두 종을 혼용하여 사용할 수 있는 근거를 확인한 것에 의미 가 있다고 사료된다. 또한 향 후 미숙과 복분자에서만 검출 될 수 있는 특징적인 성분을 발굴하는 연구도 추가적으로 필요할 것이며, 이는 ellagic acid를 함유하고 있는 산딸기 및 석류와 같은 다양한 식품소재와 혼합원료로 식품을 개발 시 미숙과 복분자의 정확한 함유량을 결정 및 검출할 수 있는 새로운 지표성분 발굴 연구도 필요할 것으로 사료된 다.

\section{요 약}

본 연구에서는 미숙과 복분자 추출물의 건강기능식품 기능성 원료 개발을 위하여 지표성분을 ellagic acid로 설정 하였으며, HPLC 분석법의 유효성을 검증하였다. 또한 국내 재배종 미숙과 복분자인 $R$ occidentalis와 중국 재배종 미숙 과 복분자인 $R$ chingii의 ellagic acid 함량 차이와 시험법 적용을 통해 원료의 상호대체 및 혼용 가능성을 확인 하였 다. 추출용매별 ellagic acid 함량을 분석한 결과, $5 \%$ 주정 추출물이 국내산과 중국산에서 각각 $16.56 \mathrm{mg} / \mathrm{g}$ 과 17.27 $\mathrm{mg} / \mathrm{g}$ 으로 가장 높게 나타났으며 두 종간의 함량 차이가 없음을 확인하였다. 향 후 두 종간의 생리활성 비교 연구를 통해 생리활성물질인 ellagic acid 함량 유사성과 같이 두 종간의 생리활성 유사성 부분의 추가 검증 연구가 필요할 것으로 사료된다.

또한 본 연구에서의 분석법 검증은 특이성, 직선성, 정확 성 및 정밀성을 확인하였으며 그 결과, 표준용액의 피크유 지시간과 spectrum이 미숙과 복분자 $5 \%$ 주정추출물과 일치 하여 특이성을 확인 하였다. 검량선의 $\mathrm{R}^{2}$ 은 0.9999 으로 높 은 직선성을 보였으며, 검출한계 $0.25 \mu \mathrm{g} / \mathrm{mL}$, 정량한계는 $0.77 \mathrm{\mu g} / \mathrm{mL}$ 였다. 회수율은 $97.54-101.01 \%$ 의 범위로 나왔고, 일내분석과 일간분석에서 상대표준편차는 국내산이 각각 $0.54-1.30 \%$ 와 $2.23-3.15 \%$, 중국산이 각각 $0.48-2.21 \%$ 와 $1.57-2.79 \%$ 로 나왔다. 따라서 본 연구를 통하여 기존의 문 헌에서 제시된 ellagic acid 분석법이 미숙과 복분자 $5 \%$ 주 정추출물에서의 지표성분 표준분석법으로 적합한 시험법 임을 재검증하였고, 건강기능식품 기능성 원료로서 ellagic $\mathrm{acid}$ 를 지표성분으로 설정하였을 경우 국내산 미숙과 복분 자인 $R$ occidentalis와 중국산 미숙과 복분자인 $R$ chingii의 수급 여건에 따라 상호 대체가 가능한 근거가 될 수 있는 자료중 하나로 활용될 수 있을 것으로 판단된다. 


\section{감사의 글}

본 연구는 농림축산식품부의 재원으로 농림수산식품기 술기획평가원의 고부가가치식품기술개발사업(116032-3) 의 지원을 받아 수행된 연구 결과이며, 이에 감사드립니다.

\section{References}

1. Bae GH (2000) The medicinal plant of Korea. Kyohasa Publishing Co Ltd, Seoul, Korea, p 231

2. Eu GS, Park MR, Yun SJ (2009) Internal transcribed spacer (ITS) regions reveals phylogenic relationships of Rubus species cultivated in Korea. Korean J Med Crop Sci, 17, 165-172

3. Eu GS, Park MR, Beak SH, Yun SJ (2010) Phylogenic relationship of Rubus cultivated in Korea revealed by chloroplast DNA spacers. Korean J Med Crop Sci, 18, 266-272

4. Lee S, You Y, Kim K, Park J, Jeong C, Jhon DY, Jun W (2012) Antioxidant activities of native Gwangyang Rubus coreanus Miq.. J Korean Soc Food Sci Nutr, 41, 327-332

5. KFRI (2012) Rubus coreanus Miq. Research Report, 484, 1-193

6. Kim LS, Youn SH, Kim JY (2014) Comparative study on antioxidant effects of extracts from Rubus coreanus and Rubus occidentalis. J Korean Soc Food Sci Nutr, 43, 1357-1362

7. Choi HR, Lee SJ, Lee JH, Kwon JW, Lee HK, Jeong JT, Lee TB (2013) Cholesterol-lowering effects of unripe black raspberry water extract. J Korean Soc Food Sci Nutr, 42, 1899-1907

8. Chae KS, Son RH, Park SY, Kim KA, Lee TB, Kwon JW (2014) Analytical method validation of ellagic acid as marker compound for standardization of black raspberry extract as functional ingredient. Food Eng Prog, $18,355-358$
9. Jung MA, Cho SH, Lee SY, Kim JH, Kim YS, Oh K, Yoo G, Lee DW, Kim S (2015) Anti-obesity effects on unripe Rubus coreanus Miquel extract in high fat diet-induced obese mice. Int J Biochem Res \& Rev, 5, 20-26

10. Oh DR, Kim Y, Choi EJ, Lee H, Jung MA, Bae D, Jo A, Kim YR, Kim S (2016) Antiobesity effects of unripe Rubus coreanus Miquel and its constituents: An in vitro and in vivo characterization of the underlying mechanism. Evid Based Complement Alternat Med, 2016, 1-15

11. Jung MA, Cho SH, Lee SY, Kim JH, Oh K, Kim YS, Yoo G, Lee DW, Kim S (2014) Effects of unripe Rubus coreanus Miquel extract on improvement of lipid metabolism in C57BL/6 mice fed a high-cholesterol diet. J Korean Soc Food Sci Nutr, 43, 650-655

12. Kim YJ, Han SH, Jeon JY, Hwang MH, Im YJ, Chae SW, Kim MG (2012) Method development of ellagic acid as marker compound for standardization of Gochang Bokbunja (Rubus coreanus Miquel) as functional ingredient. J Korean Soc Food Sci Nutr, 41, 1554-1558

13. Ministry of Food and Drug Safety. Guideline for the validation of drug analysis procedure. http://www.mfds.go.kr/index.do?mid=1162\&seq $=5549 \&$ $\mathrm{cmd}=\mathrm{v}$ (accessed September 2012)

14. Ministry of Food and Drug Safety. Guideline for the validation of drug analysis procedure. http://www.mfds. go $\cdot \mathrm{kr} /$ index $\cdot \mathrm{do} ? \mathrm{mid}=1162 \& \mathrm{seq}=10382 \& \mathrm{cmd}=\mathrm{v}$ (accessed December 2015)

15. Lee HH, Moon YS, Yun HK, Park PJ, Kwak EJ (2014) Contents of bioactive bonstituents and antioxidant activities of cultivated and wild raspberries. Korean $\mathrm{J}$ Hortic Sci Technol, 32, 115-122 